\title{
Overview on chemotaxis and acid resistance in Helicobacter pylori
}

\author{
MANUEL VALENZUELA, OSCAR CERDA and HÉCTOR TOLEDO
}

Laboratorio de Microbiología Molecular, Programa de Biología Celular y Molecular, ICBM, Facultad de Medicina, Universidad de Chile, Santiago, Chile

Key terms: Helicobacter pylori; acid tolerance response; chemotaxis; urease.

\section{INTRODUCTION}

Sensing chemicals in the environment and responding to changes in their concentrations is a fundamental property of a living cell. It is particularly important for unicellular organisms that constantly interact with the environment. Many bacterial pathogens colonize the hosts assisted by the flagella, but little is known about how these microbes use the ability to swim when they are inside of animal hosts. Motility is often driven by flagella, which is a complex extracellular structure that requires energy for operation. Motile flagellated bacteria swim toward chemical attractants and away from repellents by a mechanism known as chemotaxis. Chemotaxis is a response to microenvironmental changes and is controlled by probably the best-studied signal transduction system (Liu et al., 1997; Manson et al., 1998). Taxis responses allow motile microorganisms to rapidly move toward a microenvironment optimal for their growth and survival. The mechanism of flagellar motility and its control via chemotaxis have been studied in great detail in Escherichia coli and Salmonella enterica serovar Typhimurium (Bren and Eisenbach, 2000; Stock and Levit, 2000; Stock et al., 2000). Enteric motile bacteria can measure concentrations of chemicals outside the cell using transmembrane receptors that transmit information into the cell interior. They normally express the $m c p$ and che genes in order to regulate chemotaxis behavior. The methyl accepting chemotaxis proteins (MCPs) interact with specific ligands, while the Che proteins relay the appropriate signals from the MCPs to the flagellar motor. When attractants such as amino acids, sugars and dipeptides are present, bacteria sense the concentration gradient of attractants and swim towards them.

Enteric pathogens must survive at the acid $\mathrm{pH}$ of the stomach in order to gain entrance into the stomach or intestine to cause diseases. Pathogenic microorganisms that prefer to grow at neutral $\mathrm{pH}$ exhibit widely varying abilities to survive at extreme $\mathrm{pH}$ values. The enteric pathogens can protect themselves from acid in several basic ways. They can prevent protons from entering the cell, pump protons out of the cell, or once internal $\mathrm{pH}$ reaches a dangerous acid zone, they could protect or repair damage to macromolecules. Also, they could synthesize key enzymes that can function when internal $\mathrm{pH}$ falls. Our laboratory is currently investigating the basic response of acid tolerance in Helicobacter pylori that protect the cell further down to $\mathrm{pH} 6$ and the chemotactic properties of this microorganism. 


\section{The microorganism}

Helicobacter pylori is a neutralophilic, Gram-negative, ureolytic and motile bacterium unique in its ability to colonize the normal human stomach. It is microaerophilic, spiral-shaped bacillus, 3$5 \mu \mathrm{m}$ long and about $0.5 \mu \mathrm{m}$ in diameter, with six flagella at one pole (Dunn et al., 1997). Its genome has been sequenced and it has about 1500 open reading frames coding for a variety of proteins, and about two-thirds of known function by homology with other proteins (Tomb et al., 1997). The spiral body of this microorganism, with its bundle of unipolar flagella, is well adapted for penetrating the gastric mucous layer and for swimming rapidly in a viscous environment (Warren and Marshall, 1983; Hazel et al., 1986; Jung et al., 1997; Nakamura et al., 1998). It is also well established that $H$. pylori colonizes the mucous layer of gastric epithelium and is a causative agent for peptic ulcer disease, gastric adenocarcinoma, and gastric lymphoma (Warren and Marshall, 1983; Parsonnet et al., 1994; Dunn et al., 1997). The bacterium resides mostly within the gastric mucus layer, but a few microorganisms $(20 \%)$ are associated with the gastric epithelia, and the former population is present to replenish the latter (Kirschner and Blaser, 1995; Yoshiyama and Nakazawa, 2000). H. pylori has adapted remarkably well to variations of $\mathrm{pH}$ in their environment. Many neutralophilic organisms, such as Yersinia enterocolitica, Vibrio cholera, Escherichia coli or Salmonella typhimurium, are adapted to transit the acidity of the gastric juice (Young et al., 1996; Merrell and Camilli, 1998; Chevelli et al., 1996). They do not colonize the stomach but instead have developed acute acid resistance mechanisms. Only one organism, $H$. pylori, has adapted itself to allow not only survival in, but also habitation of the human stomach.

Several factors are thought to be involved in the colonization by $H$. pylori of the gastric mucosa, including urease activity and motility using flagella (Mobley et al., 1995; Eaton et al., 1996).

\section{Acid Resistance in H. pylori}

$H$. pylori is also unique in having a large amount of urease in the cytoplasm at neutral $\mathrm{pH}$ but is greatest in the outer portion at acidic $\mathrm{pH}$ in the wild-type strain (Mobley et al., 1995; Hong et al., 2003). Urease is synthesized constitutively by the microorganism accounting for about 10 $15 \%$ of the total protein synthesized by the bacterium (Bauerfeind et al., 1997). The enzyme is a two-subunit $\mathrm{Ni}^{+2}$ containing protein, and it does not have a signal peptide at the $\mathrm{N}$-terminal suggesting a cytoplasmic localization. However, a portion of the bacterial population releases the urease by cellular autolysis allowing the anchorage of the enzyme on the surface of intact cells (Phadnis et al., 1996). The main role of urease is thought to be the neutralization of acidic microenvironments by producing $\mathrm{NH}_{3}$ and $\mathrm{CO}_{2}$. Thereby, urease is an obvious candidate for the acid resistance mechanism of $H$. pylori. The urease activity of intact cells increased nearly exponentially when the external $\mathrm{pH}$ decreases. This activation is not due to enhanced gene expression at low external $\mathrm{pH}$ values. In cell extracts the $\mathrm{pH}$ optimum of urease activity is dependent on the buffer system and is about pH 5 in sodium citrate buffer. Since this is the cytoplasmic $\mathrm{pH}$ of the cells at $\mathrm{pH} 1$ to 2 , Stingl et al. (2002) propose that the cytoplasmic $\mathrm{pH}$ is a key factor in the in vivo activation of the urease at low external $\mathrm{pH}$ values.

With the activity of carbonic anhydrase also encoded in the genome of $H$. pylori, the $\mathrm{CO}_{2}$ generated will be able to increase the buffering capacity of the cytoplasm to resist internal alkalinization due to the generation of $\mathrm{NH}_{3}$. The $\mathrm{NH}_{3}$ produced can act as a buffer leaving the bacterial cytoplasm and entering the bacterial periplasm, by the formation of $\mathrm{NH}_{4}{ }^{+}$. It was previously believed that urease located on the cell surface created a neutral microenvironment that was conducive to bacterial survival, however it has been shown that intracellular urease actually plays a key role in promoting acid resistance (Scott et al., 2002). This role results from the availability of urease. 
There are seven genes within the urease operon, ureABIEFGH, ure $A$ and $u r e B$ are the structural subunits of the urease, whereas ureE, $F, G$ and $H$ are thought to be accessory genes necessary for formation of an active urease by insertion of $\mathrm{Ni}^{+2}$ into the UreA/UreB protein complex. Their removal results in loss of urease activity. ureI is not essential for the activity of urease (Sachs et al., 2003).

The dilemma about how intracellular urease gains access to its extracellular substrate was recently solved by the identification of UreI as an inner membrane proton-gated urea-specific channel (Weeks et al., 2000). This work demonstrated that the UreI pore opens, as the $\mathrm{pH}$ of the medium drops below $\mathrm{pH} 5.5$ and cytoplasmatic urease is able to gain access to the urea. As the enzyme activity neutralizes the local environment, the pore closes and the urea transport stops, thus providing a regulated level of urease activity. Urea in the gastric juice is able to access the intrabacterial urease if periplasmatic $\mathrm{pH}$ falls below 6 owing to $\mathrm{pH}$-gating of the urea channel, UreI. As a result of this, $\mathrm{NH}_{3}$ is formed and neutralizes the bacterial periplasm to a $\mathrm{pH}$ 6.2. Urease shifts from the cytoplasm to the outside of the cell as a result of an extracellular decrease in $\mathrm{pH}$. This difference is independent of the presence of urea, but it is UreI-dependent, suggesting an additional role of UreI in ureasedependent acid resistance (Hong et al., 2003).

Site-directed mutagenesis and chimeric analysis have identified several amino acids involved in maintaining the closed state of channel UreI at neutral pH (Sachs et al., 2003). Also it was concluded that the first periplasmatic loop of UreI is implicated in channel opening/closing at acidic and neutral $\mathrm{pH}$, and the second periplasmic loop and the $\mathrm{C}$ terminus require protonatable amino acid residues to allow the function of the channel (Weeks and Sachs, 2001).

The UreI of $H$. pylori is homolog to UreI of $H$. hepaticus and $S$. salivarius (Beckwith et al., 2001; Chen et al., 1998). The UreI products from the three bacteria have considerable homology in their predicted membrane domains, and some in the cytoplasmic domain, and little in the periplasmic domain. Although all are urea channels, those of $S$. salivarius are equally active at neutral and acidic $\mathrm{pH}$, whereas those of $H$. pylori and $H$. hepaticus are acid activated.

In addition to this acid resistance mechanism it has been shown by $2-\mathrm{D}$ isoelectric focusing non-equilibrium $\mathrm{pH}$ gel electrophoresis that $H$. pylori has a ureaseindependent acid stress response system (Toledo et al., 2001; Toledo et al. 2002). This mechanism shows that about 49 proteins change their levels of expression due to the acidic $\mathrm{pH}$, operate at mild acidic $\mathrm{pH}$ and they are under Fur control (Valenzuela and Toledo, personal communication). In addition to these mechanisms, other acid-inducible systems have been described: the acid tolerance response (Toledo et al., 2001, personal communication; Toledo et al., 2002; Karita and Blaser, 1998), the acid-induced expression of LPS (McGowan et al., 1998), and the inducible hsp70 stress protein (Huesca et al., 1998). Also, by using the whole genome approaches, proteomic and promoter analysis, it is known that $H$. pylori varies its gene expression when the bacteria is grown under acidic conditions (Bijlsma and Lie-A-Ling, 2000; Jungblunt et al., 2000; Ang et al., 2001; Allan et al., 2001; Dong et al., 2001; Toledo et al., 2002; Merrell et al., 2003; McGowan et al., 2003). However, there is a general lack of agreement between these studies emphasizing the complexity of $H$. pylori's response to acid and the difficulty in comparing single time point experiments for the assessment of global transcription or global translation.

\section{Chemotaxis in H. pylori}

H. pylori flagella contain two flagellin molecules, FlaA the major species, and FlaB, which is expressed in minor amounts (Josenhans et al., 1995; O’Toole et al., 2000). Flagellar motion appears to be essential for infection of animal models, since deletion mutants of the flagellar system are also unable to colonize (Foynes 
et al., 1999). Both flagellin molecules are necessary for full motility on soft agar plates and for full colonization of gnotobiotic piglets, whereas an aflagellated strain colonizes the stomach less frequently (Eaton et al., 1996). H. pylori apparently expresses six Che cytoplasmatic signal transduction proteins that regulate the swimming of the bacteria and are the products of the following ORFs: HP0019 (cheV), HP0393 (cheV), HP0616 (cheV), HP0391 (cheW), HP1067 (cheY), and HP0392 (cheA) (Tomb et al., 1997; Foynes et al., 2000; Pittman et al., 2001). In addition to these components, there is a family of transmembrane proteins, the methylaccepting chemotaxis proteins or MCPs, with putative receptor functions, known as HP0082, HP0099, HP0103; these are orthologs to $t \operatorname{lp} C$, $t l p A$ and $t p l B$ from Bacillus subtilis, respectively (Tomb et al., 1997).

In the stomachs of infected patients, the bacteria reside mainly in the mucous layer (Yoshida et al., 1993; Kirschner and Blaser, 1995). Because the gel layer has a rapid turnover (Messier and Leblond, 1960), the bacterium proliferating in the mucous layer should have the ability to move toward the epithelial cell surface, against the mucous flow toward the duodenum. We hypothesize that chemotaxis in $H$. pylori must be crucial for bacteria colonization and persistent infection.

Recently, it has been demonstrated that $H$. pylori has the ability to sense and move towards urea, sodium bicarbonate, sodium ions (Mizote et al., 1997) and also to aspartate and serine (Toledo and Rivas, 1999, personal communication; Cerda et al., 2003). Urea is synthesized in the liver, circulated by the blood stream, and secreted into the gastric juice through a capillary network beneath the gastric epithelial surface (Niethercut et al., 1993). Thus, a concentration gradient of urea is formed in the gastric mucus layer, which should be sensed by $H$. pylori. Bicarbonate is also secreted into the gastric mucosa by chloridebicarbonate exchangers localized in parietal cells and $\mathrm{Na}^{+}-\mathrm{H}^{+}$exchangers distributed in the mucous neck, chief, and mucous surface cells, respectively (Stuart-Tilley et al.,
1994). In addition, H. pylori might be able to swim fast at low $\mathrm{pH}$ because the flagellar motor is powered by a proton motive force (Yoshiyama et al., 1999). Thus, orally uptaken $H$. pylori can promptly evade the acidic periphery of the mucous layer and move towards the epithelial surface by chemoattraction of substances such as urea and bicarbonate, which diffuse out from the gastric epithelial surface.

The chemotactic response to urea could be crucial not only for acid resistance, but also for colonization in the hostile environment. H. pylori in the mucus layer may sense urea and move toward the epithelial cell surface, which must be important for persistent infection of this microorganism. Our results about urea chemotaxis with four different strains indicated that $H$. pylori is not attracted by urea even if the assay is done at $\mathrm{pH} 7$ or mild acid $\mathrm{pH}$ (Cerda and Toledo, personal communication; Cerda et al., 2003). Nevertheless, these results are in disagreement with the observation of Mizote et al. (1997) that reported chemotaxis to urea in H. pylori CPY3401. This different response could be attributed to the presence of the surface urease in H. pylori (Phadnis et al., 1996), that may hydrolyze the urea rapidly before becoming a signal to chemotactic system or, each $H$. pylori clinical isolate differs genetically from most other independent isolates based on DNA fingerprint and sequence analysis (Akopyanz et al., 1992; Achtman et al., 1999). Superimposed on this great general diversity, several sub-populations of $H$. pylori have been identified. Those are relatively distinct genetically, being each of them specific to a different geographic region or human ethnic group (Achtman et al., 1999; Jeong et al., 2000; Kersulyte et al., 2000).

\section{Physiological significance of chemotaxis} in H. pylori

Nitric oxide (NO), the NO synthase product, is known to play an important role in host defense against a variety of microbes (Doi et al., 1993; Fang, 1997; Nathan, 1997) although NO itself does not show sufficient 
antimicrobial activity (Yoshida et al., 1993; Kaplan et al., 1996). Peroxynitrite (ONOO-), a metabolite of $\mathrm{NO}$, is considered to be responsible for the antimicrobial effect. $\mathrm{NO}$ and superoxide $\left(\mathrm{O}_{2}^{-}\right)$react forming $\mathrm{ONOO}^{-}$, a strong oxidant and nitrating agent (Beckman et al., 1990; Ischiropoulos, 1998). In recent years, increased expression of inducible NO synthase (iNOS) has been confirmed in $H$. pylori-infected gastric tissues of patients and experimental animals (Tatemichi et al., 1998; Fu et al., 1999; Goto et al., 1999). Furthermore, it has recently been reported that not only phagocytic inflammatory cells but also $H$. pylori itself produce $\mathrm{O}_{2}^{-}$(Nagata et al., 1998), which indicates that $\mathrm{ONOO}^{-}$may be formed into and around the bacteria in vivo. Consequently, $\mathrm{ONOO}^{-}$may function as a major bactericidal effector for $H$. pylori in the stomach. Recently, Kuwahara et al. (2000) reported that $\mathrm{CO}_{2}$ formed by bacterial urease inhibits the reactivity of $\mathrm{ONOO}^{-}$with the bacterial components and accelerates its decomposition outside the bacterial cells. Also, formation of nitrotyrosine in $H$. pylori was suppressed by the addition of urea or sodium bicarbonate. In this context, it is quite reasonable to think that $H$. pylori has evolved with a system capable of detoxifying $\mathrm{ONOO}^{-}$, and hence steady and sustained colonization in the infected stomach is facilitated.

Bicarbonate is also secreted into the gastric mucosa (Stuart-Tilley et al., 1994) and chemotactic response to sodium bicarbonate (Cerda and Toledo, personal communication; Cerda et al., 2003; Mizote et al, 1997) may contribute to the persistence of $H$. pylori in the gastric epithelia and in the gastric mucus layer. Gastric mucosa is markedly adverse to bacterial colonization, as the physical and chemical barriers encountered (mucus, enzymes, and acid) inhibit colonization by common bacteria.

Arginine has a guanidine chemical group that is close to the chemical structure of urea. Cerda demonstrated that H. pylori also shows chemotaxis to arginine (Cerda and Toledo., personal communication; Cerda et al., 2003). Amino acid metabolism is essential for H. pylori growth (Marais et al., 1999). This microorganism does not synthesize L-arginine (Tomb et al., 1997; Doig et al., 1999) and therefore it must obtain that amino acid from extracellular sources. In this way chemotaxis to arginine could play a role allowing the bacteria to find the arginine source.

It has been propose that $H$. pylori arginase inhibits nitric oxide production by activated macrophages at physiological concentrations of L-arginine, the common substrate for NO synthase and arginase. On the other hand, inactivation of the gene rocF, encoding constitutively expressed arginase in $H$. pylori, restored high-output NO production by macrophages, resulting in marked NO-dependent killing of $H$. pylori (Gobert et al., 2001). This observation indicates that the bacterial arginase has evolved as a survival mechanism that may contribute to the ability of $H$. pylori to successfully colonize the human stomach. Also, arginine could protect the microorganism from toxic effects of gastric acidity by raising the $\mathrm{pH}$ of its microenvironment. Being a substrate of arginase, a highly active enzyme of the urea cycle (Mendz and Hazell, 1996), arginine would be converted to urea, which in turn is the substrate of urease, an enzyme that has been accepted as an environmental modulator. In addition, the high-frequency usage of arginine, and also lysine, in $H$. pylori proteins (Tomb et al., 1997) may be one adaptation that favors survival in acidic environments.

Arginine is not used as a nitrogen source. It has been postulated that ammonium can be obtained by deamination of asparagine, aspartate and glutamine (Mendz and Hazell, 1995). It has also been proposed that it could be the major source of carbon, converting it into $\alpha$-ketoglutarate, which can be routed throughout the majority of central metabolism.

The scavenging of arginine, bicarbonate and other substances like urea is an important factor for $H$. pylori colonization and persistence in the gastric mucus layer and motility plays a key role. In this way chemotaxis may play a fundamental role in these processes. 


\section{ACKNOWLEDGMENTS}

This work received financial support from FONDECYT 1980721 and ENL-2001/03.

\section{REFERENCES}

ACHTMAN M, AZUM T, BERG D E, ITO Y, MORELLI G, PAN Z J, SUERBAUM S, THOMPSON A, VAN DER ENDE A, VAN DOORN L J (1999) Recombination and clonal groupings within Helicobacter pylori from different geographical regions. Mol Microbiol 32:459-470

AKOPYANZ N, BUKANOV N O, WESTBLOM TU, KRESOVICH S, BERG DE (1992) DNA diversity among clinical isolates of Helicobacter pylori detected by PCR-based RAPD fingerprinting. Nucleic Acids Res 20:5137-5142

ALLAN E, CLAYTON CL, MCLAREN A, MCLAREN A, WALLACE DM, WREN BW (2001) Characterization of the low-pH responses of Helicobacter pylori using genomic DNA arrays. Microbiology 147: 2285-2292

ANG S, LEE CZ, PECK K, SINDICE M, MATRUBUTHAM U, GLEESON MA, WANG JT (2001) Acid-induced gene expression in Helicobacter pylori: study in genomic scale by microarray. Infect Immun 69:1679-1686

BAUERFEIND P, GARNER R, DUNN BE, MOBLEY H (1997) Synthesis and activity of Helicobacter pylori urease and catalase al low pH. Gut 40:25-30

BECKMAN JS, BECKMAN TW, CHEN J, MARSHALL PA, FREEMAN BA (1990) Apparent hydroxyl radical production by peroxynitrite: implications for endothelial injury from nitric oxide and superoxide. Proc Natl Acad Sci USA 87:1620-1624

BECKWITH CS, McGEE DJ, MOBLEY HL, RILEY LK (2001) Cloning, expression, and catalytic activity of Helicobacter hepaticus urease. Infect Immun 69:59145920

BIJLSMA JJ, LIE-A-LING M (2000) Identification of loci essential for the growth of Helicobacter pylori under acidic conditions. J Infect Dis 182:1566-1569

BREN A, EISENBACH M (2000) How signals are heard during bacterial chemotaxis: protein-protein interactions in sensory signal propagation. J Bacteriol 182:6865-6873

CASTANIE-CORNET M-P, PENFOUND TA, SMITH D, ELLIOTT JF, FOSTER JW (1999) Control of acid resistance in Escherichia coli. J Bacteriol 181:35253535

CERDA O, TOLEDO H (2002) The Hp0099 ORF is a methyl accepting chemotactic protein in Helicobacter pylori. Biol Res 35:R-111 (156)

CERDA O, RIVAS A, TOLEDO H (2003) Helicobacter pylori strain ATCC700392 encodes a methylaccepting chemotaxis receptor protein (MCP) for arginine and sodium bicarbonate. FEMS Microbiol Letters 224:175-181

CHEN YY, WEAVER CA, MENDELSOHN DR, BURNE RA (1998) Transcriptional regulation of the Streptococcus salivarius 57.I urease operon. J Bacteriol 180:5769-5775
CHEVELLI AM, ARNOLD KW, BUCHRIESER C, CHENG CM, KASPER CW (1996) RpoS regulation of acid, heat, and salt tolerance in Escherichia coli. Appl Environ Microbiol 62:1822-1825

DOI T, ANDO M, AKAIKE T, SUGA M, SATO K, MAEDA H (1993) Resistance to nitric oxide in Mycobacterium avium complex and its implication in pathogenesis. Infect Immun 61:1980-1989

DOIG P, DE JONGE BL, ALM RA, BROWN ED, URIANICKELSEN M, NOONAN B, MILLS S, TUMMINO P, CARMEL G, GUILD BC, MOIR DT, VOVIS GF, TRUST TJ (1999) Helicobacter pylori physiology predicted from genomic comparison of two strains. Microbiol Mol Biol Rev 63:675-707

DONG Q, HYDE D, HERRA C, KEAN C, MURPHY P, O'MORAIN CA, BUCKLEY M (2001) Identification of genes regulated by prolonged acid exposure in Helicobacter pylori. FEMS Microbiol Letters 196: 245-249

DUNN BE, COHEN H, BLASER MJ (1997) Helicobacter pylori. Clin Microbiol Rev 10:720-741

EATON KA, SUERBAUM S, JOSENHANS C, KRAKOWKA S (1996) Colonization of gnotobiotic piglets by Helicobacter pylori deficient in two flagellin genes. Infect Immun 64:2445-2448

FANG FC (1997) Mechanisms of nitric oxide-related antimicrobial activity. J Clin Investig 99:2818-2825

FOYNES S, DORRELL N, WARD SJ, STABLER RA, MCCOLM AA, RYCROFT AN, WREN BW (2000) Helicobacter pylori possesses two Che response regulators and a histidine kinase sensor, CheA, which are essential for chemotaxis and colonization of the gastric mucosa. Infect Immun 68:2016-2023

FU S, RAMANUJAM KS, WONG A, FANTRY GT, DRACHENBERG CB, JAMES SP, MELTZER SJ, WILSON KT (1999) Increased expression and cellular localization of inducible nitric oxide synthase and cycloxygenase 2 in Helicobacter pylori gastritis. Gastroenterology 116:1319-1329

GOBERT AP, MCGEE DJ, AKHTAR M, MENDZ GL, NEWTON JC, CHENG Y, MOBLEY HLT, WILSON KT (2001) Helicobacter pylori arginase inhibits nitric oxide production by eukaryotic cells: A strategy for bacterial survival. Proc Natl Acad Sci USA 98:1384413849

GOTO T, HARUMA K, KITADAI Y, ITO M, YOSHIHARA M, SUMII K, HAYAKAWA N, KAJIYAMA G (1999) Enhanced expression of inducible nitric oxide synthase and nitrotyrosine in gastric mucosa of gastric cancer patients. Clin Cancer Res 5:1411-1415

HAZEL SL, LEE A, BRADY L, HENNESSY W (1986) Campylobacter pyloridis and gastritis: association with intercellular spaces and adaptation to an environment of mucus as important factors in colonization of the gastric epithelium. J Infect Dis 153:658-663

HONG W, SANO K, MORIMATSU S, SCOTT DR, WEEKS DL, SACHS G, GOTO T, MOHAN S, HARADA F, NAKAJIMA N, NAKANO T (2003) Medium pH-dependent redistribution of the urease of Helicobacter pylori. J Med Microbiol 52:211-216

HUESCA M, GOODWIN A, BHAGWANSINGH A, HOFFMAN P, LINGWOOD CA (1998) Characterization of an acidic-pH-inducible stress protein (hsp70), a putative sulfatide binding adhesin, from Helicobacter pylori. Infect Immun 66:4061-4067 
ISCHIROPOULOS H (1998) Biological tyrosine nitration: a pathophysiological function of nitric oxide and reactive oxygen species. Arch Biochem Biophys 356:1-11

JEONG J-Y, MUKHOPADHYAY AK, DAILIDIENE D 20 other authors (2000) Sequential inactivation of rdxA (HP0954) and frxA (HP0642) nitroreductase genes causes moderate and high-level metronidazole resistance in Helicobacter pylori. J Bacteriol 182:5082-5090

JOSENHANS C, LABIGNE A, SUERBAUM S (1995) Comparative ultrastructure and functional studies of Helicobacter pylori and Helicobacter mustelae flagellin mutants: both flagellin subunits, FlaA and FlaB, are necessary for full motility in Helicobacter species. J Bacteriol 177:3010-3020

JUNG HC, KIM JM, SONG IS, KIM CY (1997) Increased motility of Helicobacter pylori by methylcellulose could upregulate the expression of proinflammatory cytokines in human gastric epithelial cells. Scand J Cli Lab Invest 57:263-270

JUNGBLUT PR, BUMANN D, HAAS G, ZIMNY-ARNDT U, HOLLAND S, LAMER S, SIEJAK F, AEBISCHER A, MEYER TF (2000) Comparative proteome analysis of Helicobacter pylori. Mol Microbiol 36: 710-725

KAPLAN SS, LANCASTER JR, BASFORD RE, SIMMONS RL (1996) Effect of nitric oxide on staphylococcal killing and interactive effect with superoxide. Infect Immun 64:69-76.

KARITA M, BLASER MJ (1998) Acid-tolerance response in Helicobacter pylori and differences between $\mathrm{cag} A^{+}$ and $\operatorname{cag} A^{-}$strains. J Infect Dis 178:213-219

KERSULYTE D, MUKHOPADHYAY AK, VELAPATIÑO B 28 other authors (2000) Differences in genotypes of Helicobacter pylori from different human populations. J Bacteriol 182:3210-3218

KIRSCHNER DE, BLASER MJ (1995) The dynamics of Helicobacter pylori infection of the human stomach. J Theor Biol 176:281-290

KUWAHARA H, MIYAMOTO Y, AKAIKE T, KUBOTA T, SAWA T, OKAMOTO S, MAEDA H (2000) Helicobacter pylori urease suppresses bactericidal activity of peroxynitrite via carbon dioxide production. Infect Immun 68:4378-4383

LIU Y, LEVIT M, LURZ R, SURETTE MG, STOCK JB (1997) Receptor-mediated protein kinase activation and the mechanism of transmembrane signaling in bacterial chemotaxis. EMBO J 16:7231-7240

MANSON MD, ARMITAGE JP, HOCH JA, MACNAB RM (1998) Bacterial locomotion and signal transduction. J Bacteriol 180:1009-1022

MARAIS A, MENDZ GL, HAZELL SL, MEGRAUD F (1999) Metabolism and genetics of Helicobacter pylori: the genome era. Microbiol Mol Biol Rev 63:642-74

MERRELL DS, CAMILLI A (1998) The cadA gene of Vibrio cholerae is induced during infection and plays a role in acid tolerance. Mol Microbiol 34:836-849

MERRELL DS, GOODRICH ML, OTTO G, TOMPKINS LS, FALKOW S (2003) pH-regulated gene expression of the gastric pathogen Helicobacter pylori. Infect Immun 71:63529-3539

McGOWAN CC, NECHEA A, THOMPSON SA, COVER TL, BLASER MJ (1998) Acid-induced expression of an LPS-associated gene in Helicobacter pylori. Mol Microbiol 30:19-31
McGOWAN CC, NECHEVA AS, FORSYTH MH, COVER TL, BLASER MJ (2003) Promoter analysis of Helicobacter pylori genes with enhanced expression at low pH. Mol Microbiol 48:1225-1239

MENDZ GL, HAZELL SL (1995) Amino acid utilization by Helicobacter pylori. Int $\mathrm{J}$ Biochem Cell Biol 27:1085-1093

MENDZ GL, HAZELL SL (1996) The urea cycle of Helicobacter pylori. Microbiol 142:2959-2967

MESSIER B, LEBLOND CP (1960) Cell proliferation and migration as revealed by radioautography after injection of thymidine-H3 into male rats and mice. Am J Anat 106:247-265

MOBLEY HLT, ISLAND MD, HAUSINGER RP (1995) Molecular biology of microbial ureases. Microbiol Rev. 59: 451-480

MIZOTE T, YOSHIYAMA H, NAKAZAWA T (1997) Urease-independent chemotaxis responses of Helicobacter pylori to urea, urease inhibitor, and sodium bicarbonate. Infect Immun 65:1519-1521

NAGATA K, YU H, NISHIKAWA M, KASHIBA M, NAKAMURA A, SATO EF, TAMURA T, INOUE M (1998) Helicobacter pylori generates superoxide radicals and modulates nitric oxide metabolism. J Biol Chem 273:14071-14073

NAKAMURA H, YOSHIYAMA H, TAKEUCHI H, MIZOTE T, OKITA K, NAKAZAWA T (1998) Urease plays an important role in the chemotactic motility of Helicobacter pylori in a viscous environment. Infect Immun 66:4832-4837

NATHAN C (1997) Inducible nitric oxide synthase: what difference does it make? J Clin Investi 100:24172423

NIETHERCUT WD, ROWE PA, NUJUMI AM, DAHILL S, MCCOLL KEL (1993) Effect of Helicobacter pylori infection on intragastric urea and ammonium concentration in patients with chronic renal failure. $J$ Clin Pathol 46:544-547

O'TOOLE PW, LANE MC, PORWOLLIK S (2000) Helicobacter pylori motility. Microb Infect 2:12071214

PARSONNET J, HASNEN S, RODRIGUEZ L, GELB AB, WARNKE RA, JELLUM E, ORENTREICH N, VOGELMAN JH, FRIEDMAN GD (1994) Helicobacter pylori infection and gastric lymphoma. N England J Med 330:1267-1271

PHADNIS SH, PARLOW MH, LEVY M, ILVER D, CAULKINS CM, CONNORS JB, DUNN BE (1996) Surface localization of Helicobacter pylori urease and a heat shock protein homolog requires bacterial autolysis. Infect Immun 64:905-912

PITTMAN MS, GOODWIN M, KELLY DJ (2001) Chemotaxis in the human gastric pathogen Helicobacter pylori: different roles for $\mathrm{CheW}$ and the three CheV paralogues, and evidence for CheV2 phosphorylation. Microbiology 147:2493-2504

SACHS G, WEEKS DL, MELCHERS K, SCOTT DR (2003) The gastric biology of Helicobacter pylori. Annu Rev Physiol 65:349-369

SCOTT DR, MARCUS EA, WEEKS DL, SACHS G (2002) Mechanisms of acid resistance due to the urease system of Helicobacter pylori. Gastroenterology 123:187-195

STINGL K, UHLEMANN E-M, SCHMID R, ALTENDORF K, BAKKER EP (2002) Energetics of Helicobacter pylori and its implications for the mechanism of urease-dependent acid tolerance at $\mathrm{pH}$ 1. J Bacteriol, 184:3053-3060 
STOCK J, LEVIT M (2000) Signal transduction: hair brains in bacterial chemotaxis. Curr Biol 10:R11-R14 STOCK AM, ROBINSON VL, GOUDREAU PN (2000) Two-component signal transduction. Annu Rev Biochem 69:183-215

STUART-TILLEY A, SARDET C, POUYSSEGUR J, SCHWARTZ MA, BROWN D, ALPER SL (1994) Immunolocalization of anion exchanger AE2 and cation exchanger NHE-1 in distinct adjacent cells of gastric mucosa. Am J Physiol 266:C559-568

TATEMICHI M, OGURA T, NAGATA H, ESUMI H (1998) Enhanced expression of inducible nitric oxide synthase in chronic gastritis with intestinal metaplasia. J Clin Gastroenterol 27:240-245

TOLEDO H, RIVAS A (1999) Helicobacter pylori and chemotaxis. Biol Res 32:R-237(128)

TOLEDO H, RIVAS A, JEREZ CA (2001) Does Helicobacter pylori possess an acid stress response? Biol Res 32:R-123(210)

TOLEDO H, VALENZUELA M, RIVAS A, JEREZ CA (2002) Acid stress response in Helicobacter pylori. FEMS Microbiol Letters 213:67-72

TOMB JF, WHITE O, KERLAVAGE AR 39 other authors. (1997) The complete genome sequence of the gastric pathogen Helicobacter pylori. Nature 388:539-547

VALENZUELA M, TOLEDO H (2002) The acid stress response is under Fur control in Helicobacter pylori. Biol Res 35:R-111(157)
WARREN JR, MARSHALL B (1983) Unidentified curved bacilli on gastric epithelium in active chronic gastritis. Lancet i 1273-1275

WEEKS DL, ESKANDARI S, SCOTT DR, SACHS G (2000) A H+-gated urea channel: the link between Helicobacter pylori urease and gastric colonization. Science 287(5452):482-5

WEEKS DL, SACHS G (2001) Sites of $\mathrm{pH}$ regulation of urea channel of Helicobacter pylori. Mol Microbiol 40:1249-1259

YOSHIDA A, AKAIKE T, DOI T, SATO K, IJIRI S, SUGA M, ANDO M, MAEDA H (1993) Pronounced enhancement of $\cdot \mathrm{NO}$-dependent antimicrobial action by an $\cdot \mathrm{NO}$-oxidizing agent, imidazolineoxyl $\mathrm{N}$-oxide. Infect Immun 61:3552-3555

YOSHIYAMA H, NAKAMURA H, KIMOTO M, OKITA K, NAKAZAWA T (1999) Chemotaxis and motility of Helicobacter pylori in a viscous environment. J Gastroenterol 34[Suppl XI]: 18-23

YOSHIYAMA H, NAKAZAWA T (2000) Unique mechanism of Helicobacter pylori for colonizing the gastric mucus. Microbes Infect 2:55-60

YOUNG GM, AMID D, MILLER VL (1996) A bifunctional urease enhances survival of pathogenic Yersina enterocolitica and Morganella morganii at low $\mathrm{pH}$. J Bacteriol 178:6487-6495 